Islamic Theology, Philosophy and Law 


\title{
Studien zur Geschichte und Kultur des islamischen Orients
}

\author{
Beihefte zur Zeitschrift „Der Islam“
}

\author{
Herausgegeben von \\ Lawrence I. Conrad \\ und Benjamin Jokisch
}

Neue Folge

Band 27

De Gruyter 


\title{
Islamic Theology, Philosophy and Law
}

\author{
Debating Ibn Taymiyya \\ and Ibn Qayyim al-Jawziyya
}

Edited by

\author{
Birgit Krawietz \\ and Georges Tamer
}

in collaboration with

Alina Kokoschka

De Gruyter 
ISBN 978-3-11-028534-5

e-ISBN 978-3-11-028540-6

ISSN $1862-1295$

\section{Library of Congress Cataloging-in-Publication Data}

A CIP catalogue record for this book has been applied for at the Library of Congress.

\section{Bibliografische Information der Deutschen Nationalbibliothek}

Die Deutsche Nationalbibliothek verzeichnet diese Publikation in der Deutschen Nationalbibliografie; detaillierte bibliografische Daten sind im Internet über http://dnb.dnb.de abrufbar.

(C) 2013 Walter de Gruyter GmbH, Berlin/Boston

Druck: Hubert \& Co. GmbH und Co. KG, Göttingen

$\infty$ Gedruckt auf säurefreiem Papier

Printed in Germany

www.degruyter.com 